\title{
Tourism, Ecology, and Sustainability: The Poetics of Self-Making
}

\author{
A. Marie Sairsingh \\ University of The Bahamas
}

\section{Abstract}

This paper explores, within an ecocritical frame, the work of two Bahamian poets that focus attention on such issues as pollution, neglect, commodification of natural resources, and the ecosocial concerns of sustainability. The piece engages a brief discussion of the ways in which their poems critique power relations within national, multinational, and global spaces. The essay examines their poetic discourse on transnational corporations which operate on principles similar to those of the plantation economies that preceded them, ultimately continuing the practice of exploitation of Caribbean labour for wealth accumulation and bodily pleasures. Strachan and Limerick's poetry functions to reclaim a sense of self, a sense of place as well as to recover a sense of history and forge a more sustainable relationship to the land and to environmental stewardship.

Within the broad frame of environmental humanities, this article uses an ecocritical lens to read two contemporary Bahamian poets whose work reflects their engagement with discourses of identity, cultural ethics, and environmental justice in the Bahamian context. "National Anthem" and "Cariconch Quincentennial," by Ian Strachan and Carlson Limerick, respectively, delineate the historical dimension of identity and of environmental concerns and illustrate how the oceanic and terrestrial environment continues to be impacted by a supracapitalist tourism agenda at the local and global levels. Equally important is the way in which Caribbean peoples are objectified as part of the natural landscape, and the way the Caribbean space is in turn marketed as sexually available (Sheller, 2004, p. 31). Given this mode of apprehending the peoples of the Caribbean, which had its emergence during the pre-colonial era, and continues into the contemporary moment, it is important to examine through a corrective lens an ecology that looks not only at the destruction of land and seascapes but also at the commodification of human life.

Strachan and Limerick's poems address ways in which the colonial period and the present imperialist era have posed ecological challenges to Bahamian landscapes, seascapes, and to the forging of viable economic and social life, or sustainable Bahamian self-making both at the personal and national levels. As DeLoughrey, Gosson, and Handley (2005) have noted, "the history of globalization and imperialism is integral to understanding contemporary environmental issues" (p. 2). Hence, the concept of "ecological imperialism," which takes together all of the foregoing, has great purchase in giving "attention to narratives and lived realities of ecological violence, crisis, and transformation that are intimately tied to imperialist practices" (p. 6).

These poets' reflections turn attention to such challenges as pollution, neglect and / or 
commodification of natural resources, and to the eco-social concerns of sustainability that arise from abuse of the environment. The poets critique power relations within the national, multinational, and global environment with respect to economics, ethics, and responsibility, suggesting that the large transnational corporations, in similar fashion to the plantation economies that preceded them, continue the practice of exploitation of Caribbean labor for wealth accumulation and bodily pleasures. Additionally, "the culture of tourism" pervades the islands, and these islands maintain tourist and service sectors that are amazingly similar to exploitative plantation economies (Strachan, 2002, p. 3).

Far from being a 20th century phenomenon, as it is often referenced, Bahamian tourism had its beginnings in the 18th century and, as Saunders (2000) notes, "as early as 1740 , Nassau had gained a reputation as a winter and health resort for 'invalids' and others from the United States and Canada seeking a change and warmer climate" (p. 73). Indeed, "the tropical environment became increasingly utilized as a symbolic location for the idealized landscapes and aspirations of the Western imagination" (Grove, 1995, p. 225). The growth and transformation of the tourism industry in the Bahamas from "elite tourism to mass tourism" (Saunders, 2000 , p. 72) by virtue of its sheer volume has, in some ways, had unwholesome effects on the economy, social and race relations as well as on the fragile infrastructure, cultural development and the environment of the Bahamas (p. 72). Indeed, by 1996, employment within the tourism industry in the Caribbean represented over 25 percent; yet, ironically, upwards of 70 percent of foreign capital earned in the tourist industry is extracted through foreign goods and services rather than re-invested in the Caribbean itself (Strachan, 2002). This practice is pervasive across the region and has implications for perceived threats to the natural environment and signals a fragile and weakening sense of place and belonging.

Despite the history of ecological imperialism, and the crucial place that the Caribbean occupies in the development of modern environmentalism (DeLoughrey, Didur, \& Carrigan, 2015), ecological concerns are surprisingly not as robustly foregrounded across the wide literary terrain as might be expected. DeLoughrey, Gosson, and Handley (2005) note that until fairly recently, the Caribbean had been bypassed in the academic discourse of environmentalism, and within literary and cultural ecocriticism, which is bewildering, given that "the roots of the current environmental crisis can be found in the age of conquest that begins in the region" ( $p$. 27). Critics and writers of the region such as Sylvia Wynter (Plot and Plantation), Wilson Harris ("numinosity" of the landscape), Edouard Glissant (landscape as monument), Kamau Brathwaite (tidalectics), Derek Walcott (Adamic consciousness), and Antonio Benitez Rojo (super-syncretism) have engaged the environment in their imaginative and theoretical work by highlighting spatial / natural relations. They situate the land and the sea within the ongoing narrative of human endeavor and assert that the region should be comprehensively studied with a mindfulness of the ecological elements coming to the fore.

Of importance is these writers' attention to the recovery of history, given that the region was "fixed in the void of an imposed nonhistory" (Glissant p. 65). Moreover, the colonial and touristic views of the islands have historically been captured through a lens that renders them ahistorical, passive and idyllic landscapes. The works examined here, I argue, present a counter-discourse to 
the notion of the idyll, and to the passivity that is often presumed of and ascribed to the land. Strachan and Limerick's poetry functions as a means through which to reclaim a sense of place as well as to recover a sense of history and forge a more sustainable relationship to the land and to environmental stewardship.

In his poem, ironically titled, "National Anthem," Strachan begins with the assertion: "this is the song / of my islands," in successive stanzas, he speaks about the "the wail / of my islands" which gives a sense of the poem as a lament. He critiques the way in which the island has become the "pleasure house of venal gods / stomping ground of gangsters / house of somnambulists" where the political will established in the Bahamas' postindependence era has seemingly become eroded. Strachan's reflection on his "atrophied islands" suggests a neglect so profound that those in power are seen as not merely ineffectual but downright destructive.

The poet's description of the docks where "slave blood and crab shit mingle" is poignantly drawn, and the echoes of slavery resonate in the present space. The lament is replete with images of waste, atrophy, and regression of a nation that is at once "sacred and sacrilegious". The neologism, "deselftion" describes a process of undoing; and speaks of experiences that erode one's sense of dignity and of belonging. Strachan addresses the need for the articulation of an ontology that restores the humanity of the denuded self. The images of the "fat Bay Street bosses," "smugglers," and "picky heads" describe the range of inhabitants and the racial segregation and social hierarchy that characterize Bahamian society.

The idea that while the inhabitants try "to remake [themselves] again" the blue eyes of an aloof god look down disapprovingly, suggests the people's metaphysical disconnection from the putative Christian god of salvation and the profound sense of alienation that this dissevering engenders. In this poem, the routine images of paradise are supplanted by those of ruin. Strachan, asserting his passion for the land he inhabits and claims ownership of, voices the necessity to redress the ravages of colonial violence inflicted upon the environment and the psyche of a people. He speaks of mangrove and marsh / lake and swamp / pine forest and coppice whose state of disarray is the result of irresponsible stewardship. This environmental neglect is, he suggests, even more apparent in the wildlife that goes unchecked and degenerates into an "army of lizards / battalion of stray dogs / palace of termites" and a host of "guerilla raccoons," showing the marked indifference and an alarming unconcern for long-term ecological wellbeing.

Hilary Beckles suggests that the indifference shown to ecological sustainability emanates out of the "culture of plantation management which continues to prevent the majority from owning land in the country [and which] has alienated people from environmental issues" (cited in DeLoughrey, Gosson, \& Handley, 2005, p. 25). Compounding the issue even more is the fact that until fairly recently, the "institutions and mechanisms that are required to best prevent the region from destroying what it needs most are absent" (Pattullo, 2006, p. 113). "Caribbean governments," Pattullo further observes, "are the worst regional environmental offenders, and even in the most liberal of democracies, the kind of participatory planning processes necessary for sustainable utilization of resources, are often absent" ( $p$. 113).

Strachan shifts his gaze to the past-when, 
in the late 1800s and early 1900s, the AngloAmerican landscape artist Winslow Homer painted natives, portraying them as "ebony Apollos / romantic savages" who "flexed and fished / on his canvases while darkie boys / dove for coins and / ran races for white bosses" (p. 20). Strachan here alludes to the mid 1900s when cruise ships would "[deposit] / pale discoverers / all in search of Eden / a smiling mammy or / black cockslinger" (p. 20). Strachan laments this brazen quest, this flagrant eroticization of the local population; his image of tourists as sexual marauders reflects that of earlier "discoverers," who came, sword in hand, and pierced the earth, symbolizing both conquest and sexual prowess. Strachan's suggestion here is that tourism rapes the land, pollutes the sea, subjugates the populace and promotes sexual debauchery. Strachan sums up his reflection by reiterating "the wail / of my islands / these atrophied islands" in which "god's blue eyes / [see] us struggle / [see] us trying to / remake / ourselves / again" (p. 21). This New World god observes indifferently the fervent effort of a people trying to redeem themselves, struggling to reclaim their ontology. The repetition of the word "again" suggests the continuing neglect and disownership of the god whom they look to, making unrequited supplication. "A sense of belonging in the Caribbean," DeLoughrey, Gosson, \& Handley (2005) observe, "is conditioned by an always-incomplete knowledge of natural and human histories and therefore necessitates recreating a sense of place in the present" (p. 20). Strachan evokes the idea of ontological reclamationof land, psyche, spirit, and self-which connects with his lament for his "dry-lands," his "sacred islands," his "I-lands" whose ecological ill-health is cause for serious concern and redress.

If Strachan's poem, "National Anthem" is a lament for environmental erosion, loss, and psychic dislocation, Limerick's poem, "Cariconch Quincentennial," written in 1992 to commemorate the five-hundredth anniversary of Columbus' landfall in the Bahamas, reflects a multiplicity of themes around ecology, colonialism, and neocolonialism. Limerick's coinage, "Cariconch," critiques the Caribbean, which has, in his view, progressed little beyond the consumerist tourism model in which the landscape and the people are offered up for the pleasure and use of Western consumers. I am reminded of Franz Fanon's prescient observations in his now classic work, Wretched of the Earth (1961) where he asserts:

The national bourgeoisie organizes centers of rest and relaxation and pleasure resorts to meet the wishes of the Western bourgeoisie. Such activity is given the name of tourism, and for the occasion will be built up as a national industry...[this class] will have nothing better to do than to take on the role of manager of Western enterprise, and it will in practice set up its country as the brothel of Europe. (cited in Kempadoo, 1999, p. 3)

In his epigraph, Limerick quotes the following line from a Bob Marley song "Pimper's Paradise" (1980) "that's all she was," clearly referencing the Bahamas as prostitute for the transnational conglomerate "big shots" of tourism who function as her pimp. This line poignantly introduces the troubling juxtaposition of sex and tourism, and the tourism worker as an embodied commodity. Limerick's tropology of the conch, captioned in different segments of the poem as "Airport Conch," "Dockside Conch," "Conch Salad," and "Conch Shell?" speaks to the presumed aphrodisiac quality of the islands. Conch, the indisputable and nationally acknowledged aphrodisiac, brings 
"pale explorers" in search of sex. Under the heading, "Airport Conch", Limerick evokes visceral responses to the "pink lips outspread / the raw nakedness / of a huge conch" erected along the roadway leading from the national airport that "indecently [assaults] the eye / juicy lure / to millions of fading Ponce de Leons / from a tired new world / discharge of turgid jets ceaseless rhythm" (p. 86). The stanza with its abounding sexual images offers up the massive conch sculpture in iconized dimension, as a troubling national symbol.

In subsequent stanzas, unvarnished references to sexual exploits address the illicit exchange under the guise of service to tourism. In the segment, "Dockside Conch" the poet captures the scene of commerce, where fishermen sell their catch to customers, eager to purchase and consume the colourless, slimy part of the conch known as the "pistol," purported to be the aphrodisiacal element. In a single, compressed image, he describes at once the eating of the conch pistol and the dockside sexual exploits:
Bare but for a single string slipped between moist full cheeks three coloured girls in the window serve their butts to the eager surge of conquistadors to the dock that takes with practiced ease the tight fit of each bulging vessel

Amid this dockside culture of wanton solicitations, and easy commercial transactions, is the eyesore of piled-up, abandoned conch shells, whose destiny is uncertain. For while some are recycled as ornaments, others remain on the dock in decomposing rancidity, an ecological blight on the environment.

In the penultimate and final stanzas, "Conch Salad" and "Conch Shell?" Limerick offers an erotic vision of insemination in which the conch "spews / its white load / seeding the lush isles / ...to the throb / of goombay / soca / and dub / no warm embrace" (p. 87). He points to loveless transactions in the "calculated act of commerce / with which the quincentennial courtesan / takes daily traffic to her couch" (p. 87). The poet delivers the core question that must be answered not only by the "courtesan" herself, but also by the nation: "are we doomed by fortune to / a lifetime on our back?" If, as Nixon suggests, informal "sexual services ...are encouraged and even promoted by the tourist industry and generally tolerated (even regulated in some places) by Caribbean governments" (2015, p. 168), such a question requires deep reflection and serious response, if equitable existence and environmental sustainability are to be achieved. Again, if tourism, as oft proclaimed, is the lifeblood of the Caribbean, how will the countries of the region ever escape being cast in international marketing efforts as places of enticement and sexual availability, where moral strictures are suspended to accommodate hedonistic pleasures, and where damage to the environment and fragile ecosystems causes little alarm?

Strachan and Limerick render works that reflect and indeed provoke deep contemplation of environmental sustainability and psychic health of the Bahamian and, by extension, the Caribbean people. In illuminating the continued threat to the environment and the impending ecocrisis, they urge redress to the ecological damage that has over time, become all too commonplace. As well, they suggest the need to reclaim ownership of the self which, like the physical environment, is objectified and diminished through psychic erosion wrought by existential hardship. These poets, like Glissant, echo the imperative "to remake oneself" (Glissant, cited in Handley, 
2007, p. 53), to continuously forge a new sense of personal and cultural identity within and against the sometimes corrosive and exploitative effects of a tourist economy.

\section{References}

DeLoughrey, E., Didur, J., \& Carrigan, A. (Eds.). (2015). Global ecologies and the environmental humanities: Postcolonial approaches. New York: Routledge.

DeLoughrey, E. M., Gosson, R. K., \& Handley, G. (Eds.). (2005). Caribbean literature and the environment: Between nature and culture. Charlottesville: University of Virginia Press.

Glissant, E. (1989). Caribbean discourse: Selected essays. Charlottesville: University of Virginia Press.

Grove, R. (1995). Green imperialism: Colonial expansion, tropical island Edens, and the origins of environmentalism, 1600-1860. Cambridge, Eng.: Cambridge University Press.

Handley, G. (2007). New world poetics: Nature and the Adamic imagination of Whitman, Neruda, and Walcott. Athens: University of Georgia Press.

Kempadoo, K. (1999). Continuities and change: Five centuries of prostitution in the Caribbean. In K. Kempadoo (Ed.), Sun, sex, and gold: Tourism and sex work in the Caribbean (pp. 3-33). Lanham, MD: Rowman \& Littlefield.

Limerick, C. (1993). Cariconch quincentennial. In I. S. Cabrera (Ed.), From the shallow seas: Bahamian creative writing today (pp. 86-87). Havana, Cuba: Casa de las Americas.

Marley, B. (1980). Pimpers paradise [Recorded by Bob Marley and the Wailers]. On Uprising [CD]. Kingston, Jamaica: Tuff
Gong/Island. (1980)

Nixon, A.V. (2015). Resisting paradise:

Tourism, diaspora, and sexuality in Caribbean Culture. Jackson: University of Mississippi Press.

Pattullo, P. (1996). Last resorts: The cost of tourism in the Caribbean. Kingston, Jamaica: Ian Randle.

Saunders, G. (2000). The impact of tourism on Bahamian society and culture: An historical perspective. Yinna: Journal of the Bahamas Association for Cultural Studies, 1, 72-87.

Sheller, M. (2004). Natural hedonism: The invention of Caribbean islands as tropical playgrounds. (pp. 23-38). In D. T. Duval (Ed.) Tourism in the Caribbean: Trends, development, prospects. New York, NY: Routledge.

Strachan, I. G. (2003). National anthem. Silk cotton soul (pp. 20-21). Nassau, Bahamas: Cerasee Books.

Strachan, I. G. (2002). Paradise and plantation: Tourism and culture in the anglophone Caribbean. Charlottesville: University of Virginia Press. 